\title{
AN EXPERIMENTAL STUDY OF THE ELECTRICAL ACTIVITY OF THE BYPASSED STOMACH IN THE ROUX-EN-Y GASTRIC BYPASS
}

\author{
Álvaro Antônio Bandeira FERRAZ1', Cristiano Souza LEÃ01, Josemberg Marins CAMPOS'1, \\ Antônio Roberto Barros COELH01, Bruno ZILBERSTEIN² and Edmundo Machado FERRAZ1
}

\begin{abstract}
Background - Surgical options for morbid obesity are diverse, and the Roux-en-Y gastric bypass, initially described by Fobi has gained popularity. Knowledge about the physiology of the bypassed stomach is limited because this newly produced segment of the stomach is inaccessible to endoscopic or contrast radiological studies. Aim - To evaluate the myoelectric activity of the bypassed stomach and its reply to the feeding. Methods - An experimental protocol was conducted to evaluate postoperative gastric bypassed motility in dogs submitted to the Roux-en-Y gastric bypass procedure. Two groups of five animals were studied on postoperative fasting and after a standard meal, recording electrical response and control activity. Both control and Roux-en-Y gastric bypass operated study group had a pair of electrodes placed on three points of the remaining stomach: fundus, body and antrum. Data registration was performed after complete ileus resolution, and analysed with DATA Q Inst. series 200. Results - The results achieved on the conditions of this study suggest that: 1. the remaining stomach maintain the same pattern of motility; 2. there is a reduced fasting electromyography activity following the Roux-en-Y gastric bypass procedure; 3 . significantly reduced fasting electric control activity when compared both groups, and a markedly reduced fasting response electric activity and; 4 . the electric response to the feeding kept the same standard of the stomach, however in a statistically reduced way. Conclusion - The electrical activity of the bypassed stomach of Roux-en-Y gastric bypass procedure kept the same pattern but in a statistically reduced number of contraction.
\end{abstract}

HEADINGS - Obesity, morbid. Bariatric surgery. Gastroplasty. Anastomosis, Roux-en-Y. Dogs.

\section{INTRODUCTION}

The surgical treatment of morbid obesity has gained large dimensions over recent years, especially because of its effectiveness in decreasing weight and reverting a large part of the associated complications ${ }^{(23,32)}$.

Currently, Roux-en-Y gastric bypass (RYGBP) is considered standard practice for bariatric surgery, but leaves a large blind gastric segment, which is very difficult to study with GI endoscopy or X-ray ${ }^{(7)}$.

Within the wide range of surgical techniques for the treatment of morbid obesity, the RYGBP, initially described by FOBI et al. ${ }^{(12)}$ and after modified by other authors ${ }^{(6)}$, creates a small gastric pouch and a large chamber excluded from the food passage. This excluded gastric chamber has been the motive for much concern $^{(4,5,7,19,20,25,29)}$ and in some countries this surgery is rarely performed ${ }^{(7)}$. A series of problems may occur due to this functional exclusion. The gastric chamber produced during RYGBP, becomes inaccessible once the surgery has been completed. This difficulty constitutes the major criticism directed towards this procedure, since it renders diagnosis and treatment of neoplasia, gastric/duodenal ulcer or choledocholithiasis extremely difficult ${ }^{(4,5,19,20,25,29)}$.

How does it react when faced with $H$. pylori colonization $?^{(10)}$ How can hemorrhaging in this stomach be dealt with? How does this stomach react with dietary stimuli? Are there any $\mathrm{pH}$ changes? Does the stomach contract? Does contractile electrical activity take place in this stomach? These are just some of the questions that have been raised, and that until now have remained unanswered.

Morbid obesity is frequently associated to gastroesophagal motility disturbances ${ }^{(15)}$. Electromyographic alterations following gastric surgeries have been discussed in the literature ${ }^{(2,13,27)}$.

The excluded stomach in RYGBP maintains its innervation. However, the electromyographic behavior of this gastric chamber is unknown during periods of fasting and eating.

Grant from the CNPq - Brazilian Government, number 300242/2003-4

${ }^{1}$ Federal University of Pernambuco (UFPE); ²São Paulo University Medical School, São Paulo, SP, Brazil.

Correspondence: Dr. Alvaro A. Bandeira Ferraz - Rua D. Sebastião Leme, 171 - apt. 2501 - Graças - 52011-160 - Recife, PE, Brasil. E-mail: aabf@truenet.com.br 
The objective of this study was to analyze in an experimental manner with dogs, the electrical control activity (ECA) and the electrical response activity (ERA) in the excluded gastric chamber of dogs submitted to RYGBP, during a period of fasting and a period immediately after ingesting a standardized diet.

\section{METHODS}

Twelve healthy, female, mixed race dogs were studied. They were divided into two paired groups, each with six animals, denominated control group and experimental group, with average body weights of $14.4 \mathrm{~kg}$ and $13.8 \mathrm{~kg}$, respectively.

Firstly, in the control group, the fur was removed from the surgical area and anti-septic was applied. A laparotomy with a midline incision was performed, followed by the implantation of three pairs of electrodes, of the cardiac pacemaker type MP285-B Monicron 2-0, in steel, covered with a layer of Teflon, measuring $60 \mathrm{~cm}$ in length and with a circular needle of $2.5 \mathrm{~cm}$, in the serous membrane of the stomach, distributed in the gastric fundus, body and antrum at the level of the greater curvature. Following this, each pair of electrodes was fixed with Prolene 000 (3-0) stitches to the stomach in order to avoid postoperative accidental dislocation of the electrodes ${ }^{(18)}$.

In the experimental group, after opening the abdominal cavities, all animals were submitted to a RYGBP, without placing a band on the gastric pouch. A gastrojejunal anastomosis was created in such a manner as to obtain a width of $5 \mathrm{~cm}$ to facilitate the passage of food during the postoperative period. Roux-en-Y anastomosis was created $25 \mathrm{~cm}$ from the gastrojejunostomy, also $5 \mathrm{~cm}$ in width. All sutures were performed with Prolene 000 (3-0). A sequence of paired electrodes were then implanted into the excluded gastric chamber, along the gastric fundus, body and antrum, at the level of the greater curvature, in order to obtain simultaneous registers through three independent channels, one for each gastric segment (Figure 1).

The electrodes were brought through to the exterior via the abdominal wall, following the same sequence. The electrodes were fixed to the abdominal wall using shirt buttons, in order to avoid accidental removal by any uncontrolled movement by the

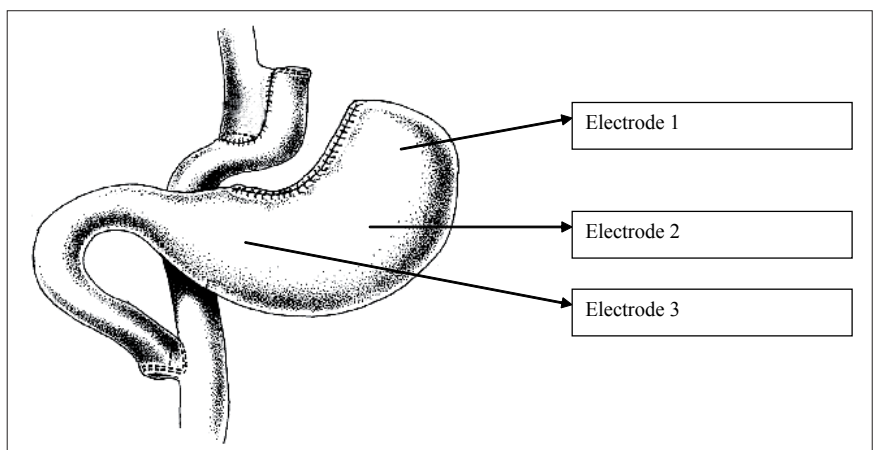

FIGURE 1. Schematic drawing indicating the implantation sites of the pairs of electrodes in the excluded gastric chamber animal. Although readings were taken while the animals were at rest, they were nonetheless awake.

This measure guaranteed that the electrodes remained attached to the stomach wall of 10 of the 12 animals $(84 \%)$, thus constituting an effective method ${ }^{(18)}$.

The average surgical time for the control group was 58.66 $\pm 12.17 \mathrm{~min}$, while that of the experimental group was 102.40 $\pm 13.99 \mathrm{~min}$.

Data were collected on the 2 nd postoperative day, after the animal had defecated for the first time in the kennels, an important sign indicating the postoperative recuperation of the ileum. Data were collected in two phases: the first, during a period of fasting and the second after the ingestion of $50 \mathrm{~g}$ (75 calories) of standard industrialized food, as shown in Figure 2 .

\begin{tabular}{|lcc|}
\hline $80 \%$ humidity & $2 \%$ fiber & $3.0 \%$ minerals \\
$10 \%$ protein & $0,5 \%$ calcium & $10 \times 103$ vitamin A \\
$4 \%$ ether extract & $0,1 \%$ phosphorus & $10 \times 102$ vitamin D \\
\hline
\end{tabular}

FIGURE 2. Composition of diet offered to the animals

The records of the electrical signals were processed by a hardware unit composed of amplifier, filter, PC equipped with data acquisition board (DATA Q Inst., Akron, OH, series 200), that captures previously determined frequencies, in a range of between $0.02 \mathrm{~Hz}$ and $10 \mathrm{~Hz}^{(9,11,18)}$.

Once the signals were amplified and the interference removed, data reading was stored using the program WINDAC200 with Windows. Data acquisition was achieved with a sample of 40 points per second $(\mathrm{Hz})$. Data was then analyzed by means of algorithms based on the Fourier series. In this manner, each electrode was divided into individual files which were digitally band-pass filtered between 1 and $10 \mathrm{~Hz}$ for ERA and below 0.2 for ECA. For ERA, all frequency components outside the $1-10 \mathrm{~Hz}$ band were set to zero, and the inverse FFT converted the data back to the time domain (Figure 3). The same processing was used for $\mathrm{ECA}^{(18)}$.

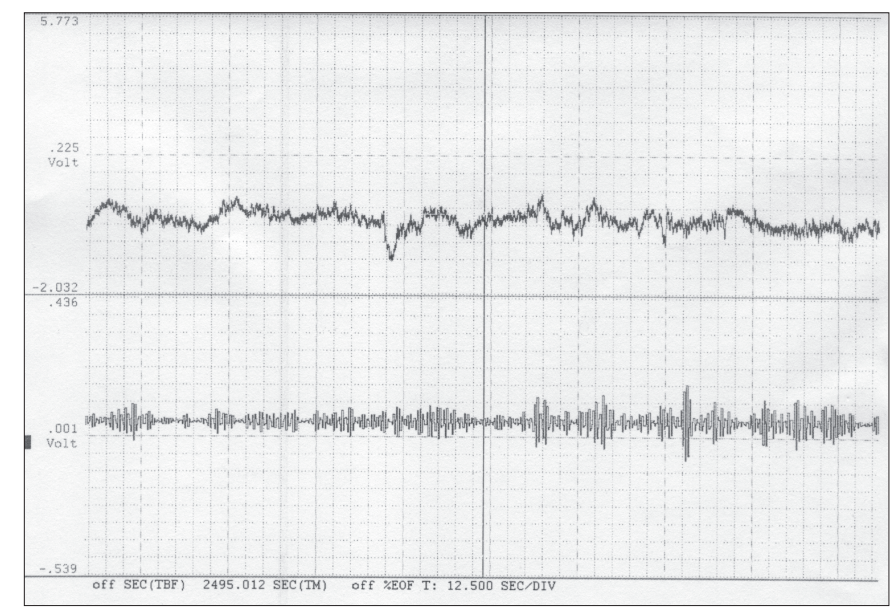

FIGURE. 3. FFT analysis of the electrical response activity (ERA) of the gastric fundus 
ECA and ERA data was investigated in the three gastric segments: fundus, body and antrum, during fasting and postprandial periods.

The following procedures were used in the statistical analysis: the sample size was calculated considering $\alpha=0.05$ and $\beta=0.2$; the number of five animals, proved to be enough for the objectives traced.

Analysis of variance for repeated measures: this method was used to study the behavior of the electrical activity in the gastric segments of the two animal groups. Initially, it was verified if the average behavior of the electrical activity of the gastric segments was similar in the two groups, or rather, if there was no interaction between groups and gastric segments. In cases where this hypothesis was not rejected, the analysis continued testing the effect of the surgery and the effect of the gastric segment. In contrary conditions, the analysis was conducted by comparing the averages of the gastric segments of each group and comparing the average of one of the same gastric segments in the control group and the experimental group;

Multiple comparisons using the Bonferroni method: this procedure was used to identify pairs of gastric segments with statistically significant average differences;

The Student $t$ test: applied to compare the averages of the same gastric segment in the control group and the experimental group.

The established level of significance for the analysis was 0.05 .

\section{RESULTS}

\section{Electrical control activity during fasting}

The result of the analysis of variance for repeated measures indicated that the electrical control activity during fasting, presented a statistically significant behavior difference between: a) the control and experimental groups $(P=0.004)$; b) and between the gastric segments: fundus, body and antrum $(P=0.005)$. With intervention, the electrical control activity decreased in a uniform manner regardless of gastric segments. This decrease was significantly different from zero $P=0.004$; IC 95\%: 0.7 to 2.6 cycles/minute (Table 1, Figure 4). Gastric segments with statistically significant average differences were identified using the Bonferroni multiple comparisons procedure. Only the fundus and the antrum in both the control and experiment groups presented evidence of any significant difference between

TABLE 1. Electrical control activity (cycles/minute) in the gastric fundus, body and antrum in the control and experimental groups, during fasting

\begin{tabular}{lcccccc}
\hline & \multicolumn{3}{c}{ Control group } & \multicolumn{3}{c}{ Experimental group (RYGBP) } \\
\cline { 2 - 7 } & Fundus & Body & Antrum & Fundus & Body & Antrum \\
\hline Dog 1 & 6.9 & 6.9 & 6.7 & 4.4 & 4.0 & 5.1 \\
Dog 2 & 4.3 & 4.5 & 4.8 & 3.8 & 4.1 & 4.6 \\
Dog 3 & 4.2 & 7.0 & 7.6 & 3.3 & 4.6 & 5.4 \\
Dog 4 & 5.7 & 4.9 & 6.3 & 3.2 & 4.1 & 4.0 \\
Dog 5 & 5.4 & 5.2 & 7.5 & 3.0 & 4.8 & 5.0 \\
Average & 5.3 & 5.7 & 6.6 & 3.5 & 4.3 & 4.8 \\
Standard deviation & 1.1 & 1.2 & 1.1 & 0.6 & 0.4 & 0.5 \\
\hline
\end{tabular}

the averages of the electrical control activity. The average was lower in the fundus. The difference of averages between the two segments was estimated at 1.3 cycles/minute. This difference was statistically significant (Figure 4).

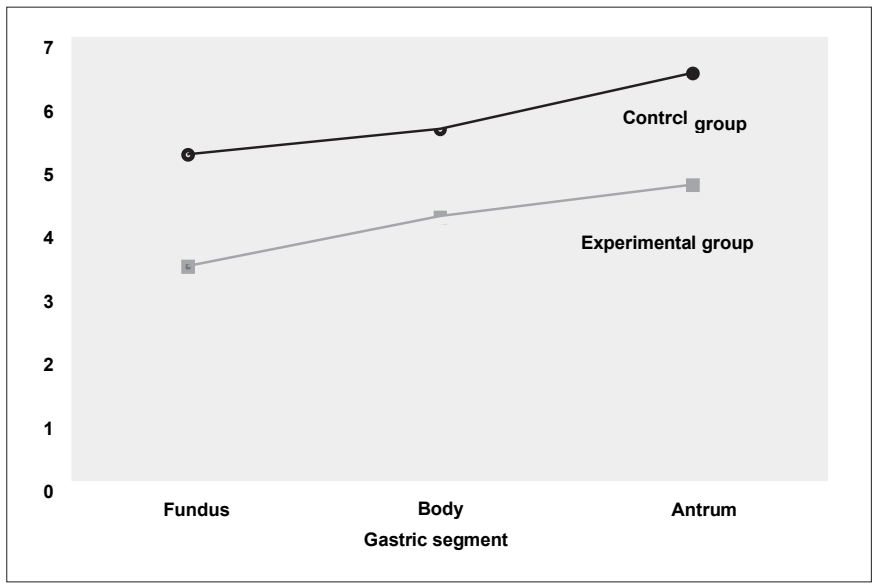

FIGURE 4. Averages of electrical control activity during fasting

\section{Electrical control activity during the postprandial period}

During the postprandial period, the result of the analysis of variance analysis for repeated measures, and applied only to the control group, illustrated that in this group, the observed differences of electrical control activity in the three gastric segments were not statistically significant, $P=0.721$ (Figure 5).

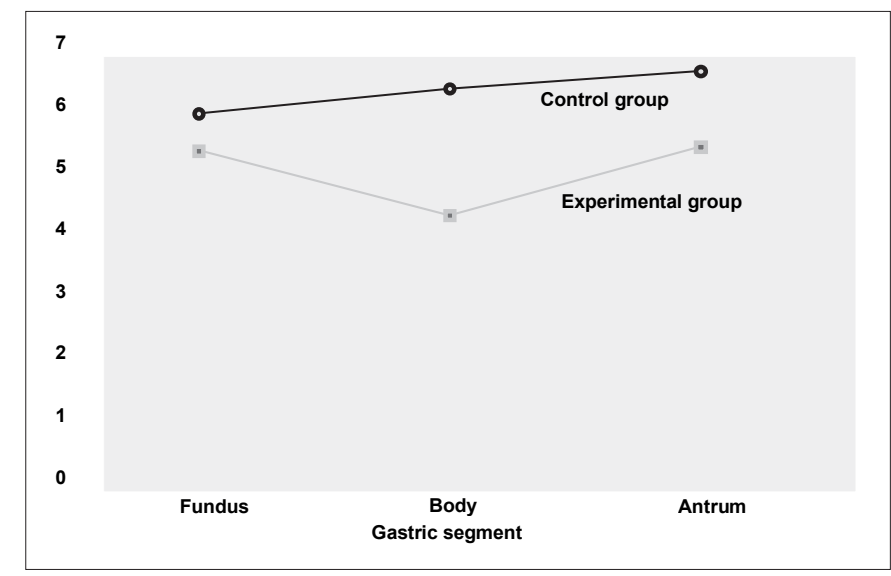

FIGURE 5. Averages of electrical control activity in the immediate postprandial period

When applied to the experimental group (RYGBP), the analysis of variance for repeated measures illustrated that the electrical control activity during the immediate postprandial period presented a statistically significant behavior difference $(P=0.003)$. Gastric segments with statistically significant average differences were identified using the Bonferroni multiple 
comparison procedure. Statistically significant average differences were identified between the fundus and the body and between the body and the antrum (Tables 2,3 ).

TABLE 2. Electrical control activity (cycles/minute) of the gastric fundus, body and antrum in the control and experimental groups, during the immediate postprandial period

\begin{tabular}{lcccccc}
\hline & \multicolumn{3}{c}{ Control group } & \multicolumn{3}{c}{ Experimental group (RYGBP) } \\
\cline { 2 - 7 } & Fundus & Body & Antrum & Fundus & Body & Antrum \\
\hline Dog 1 & 5.0 & 5.6 & 5.2 & 5.0 & 4.1 & 5.2 \\
Dog 2 & 6.1 & 5.2 & 5.4 & 5.9 & 4.5 & 5.2 \\
Dog 3 & 8.3 & 10.3 & 7.9 & 4.8 & 3.9 & 5.3 \\
Dog 4 & 4.8 & 5.0 & 5.0 & 4.8 & 4.0 & 5.8 \\
Dog 5 & 4.9 & 5.0 & 9.0 & 5.6 & 4.4 & 4.9 \\
Average & 5.8 & 6.2 & 6.5 & 5.2 & 4.2 & 5.3 \\
Standard deviation & 1.5 & 2.3 & 1.8 & 0.5 & 0.3 & 0.3 \\
\hline & & & & & &
\end{tabular}

TABLE 3. Differences of the average electrical control activity during the postprandial period of the three gastric segments in the experimental group (RYGBP)

\begin{tabular}{lccc}
\hline Compared segments & $\begin{array}{c}\text { Difference of } \\
\text { averages }\end{array}$ & Value P & $\begin{array}{c}\text { 95\% interval of reliability for } \\
\text { the difference of the averages }\end{array}$ \\
\hline Fundus - Body & 1.0 & 0.002 & 0.6 a 1.5 \\
Fundus - Antrum & -0.1 & 1.000 & -1.4 a 1.3 \\
Body - Antrum & -1.1 & 0.028 & -2.0 a -0.2 \\
\hline
\end{tabular}

11 C95\% $=95 \%$ Interval of reliability for the difference of averages

For each gastric segment, the result of the Student $t$ test illustrated that the comparison of the averages of the electrical control activity in the two groups was not statistically significant.

\section{Electrical response activity during immediate postprandial period}

The result of the analysis of variance for repeated measures illustrated that the electrical response activity during the immediate postprandial period presented a statistically significant behavioral difference between: a) the control and experimental groups $(P=0.001)$; and $\mathrm{b})$ the gastric segments: fundus, body and antrum $(P<0.001)$. There was also a statistically significant interaction between the groups and the gastric segments $(P=0.004)$ (Figure 6).

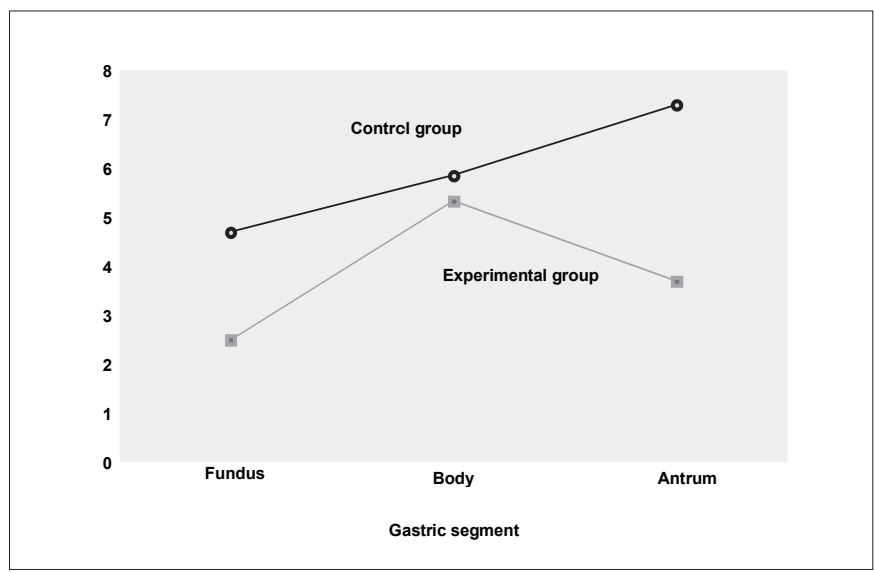

FIGURE 6. Averages of electrical response activity
For each gastric segment, the result of the Student $t$ test illustrated that the comparison of the averages of the electrical response activity in the two groups were statistically significant in the fundus $(P=0.018)$ and antrum $(P=0.003)$ segments (Table 4).

TABLE 4. Electrical response activity (contractions/minute) of the gastric fundus, body and antrum of the control and experimental groups during the immediate postprandial period

\begin{tabular}{lcccccc}
\hline & \multicolumn{3}{c}{ Control group } & \multicolumn{3}{c}{ Experimental group (RYGBP) } \\
\cline { 2 - 7 } & Fundus & Body & Antrum & Fundus & Body & Antrum \\
\hline Dog 1 & 4.2 & 5.1 & 7.2 & 2.8 & 5.1 & 4.2 \\
Dog 2 & 6.1 & 6.2 & 6.4 & 2.1 & 4.4 & 3.8 \\
Dog 3 & 6.0 & 6.7 & 8.6 & 2.9 & 7.4 & 3.2 \\
Dog 4 & 3.1 & 5.8 & 5.6 & 2.0 & 4.8 & 3.8 \\
Dog 5 & 4.0 & 5.4 & 8.6 & 2.6 & 4.9 & 3.4 \\
Average & 4.7 & 5.8 & 7.3 & 2.5 & 5.3 & 3.7 \\
Standard deviation & 1.3 & 0.6 & 1.3 & 0.4 & 1.2 & 0.4 \\
\hline
\end{tabular}

For each group, the gastric segments with statistically significant average differences were identified using the Bonferroni multiple comparison procedure. In the control group, only the fundus and the antrum presented significant differences between the averages of the electrical response activity. The difference of averages between the two segments was estimated at 2.6 contractions/minute. This difference was significantly different from zero.

In the experimental group, the fundus and the body, and the body and the antrum presented significant differences between the averages of the electrical response activity. Compared to the fundus, the average of the body was greater. The difference of averages between the two segments was estimated at 2.8 contractions/minute. This difference was significantly different from zero. In comparison to the body, the lowest average was that of the antrum. The difference of the averages between these two segments was estimated at 1.6 contractions/minute. This difference was significantly different from zero.

\section{COMMENTS}

The electrical activity of the stomach consists of rhythmic waves of depolarization and repolarization of the smooth muscle, determining the so-called electrical control activity (depolarization phase) and the electrical response activity

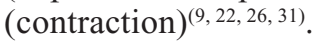

The RYGBP does not section nerve terminals, and the vagal innervation of the excluded stomach remains intact ${ }^{(14)}$.

Surgeries carried out on the stomach interfere with electromyographic standards and consequently on the contracting capacity of this organ. Numerous studies in the literature have demonstrated alterations in gastric leakage when gastrectomies occur and, especially, when there is a lesion of the vagus, since the degree of retardation or acceleration of the leakage will depend on the technique used, the area of the gastric section and the type of vagotomy carried out ${ }^{(8,13,21,24)}$. 
After the section and re-anastomosis of the stomach of six dogs, with three at antrum level and three at body level, with pre and post anastomosis electrode implants, SHIMASAKI ${ }^{(28)}$ demonstrated intrinsic gastric automatism. In a further study, with similar methodology and section, vagotomy and re-anastomosis of the stomach, it was observed that the electrical control activity in the proximal stomach was unaltered and the electrical activity of the distal stomach recuperated after the 30th postoperative day ${ }^{(1)}$. In dogs studied by KONEGAWA ${ }^{(16)}$, where a proximal vagotomy with subtotal gastrectomy was carried out, it was observed through implanted electrodes that ECA was prolonged during fasting, and when food was ingested, even with different compositions, a near normal rhythm occurred after the fourth week. ANDO ${ }^{(1)}$ and KUWASHIMA $^{(17)}$ carried out partial gastrectomies with different vagotomy techniques in all the animals and the electrical control activity had recuperated on around the 15th postoperative day. Van DIELEN et al. ${ }^{(30)}$ analyzing the myoelectric activity of the stomach submitted to a restricted gastroplasty, demonstrated that there were no great myoelectrical alterations of the gastric activity, and that the clinical problems of motility presented after this type of surgery are not related to myoelectric malfunctions of the stomach.

In the present study a partial section of the stomach without vagotomy was conducted, with the creation of a small chamber in the lesser curvature, where a gastrojejunal anastomosis was created. A large gastric chamber remained in the abdominal cavity composed of the fundus, part of the body and the antrum with the myoelectric activity under the influence of the intrinsic, extrinsic and endocrine nervous systems. Within this large chamber, electrodes were implanted in the fundus, body and antrum, to analyze the electrical control activity of the jejunum and, after the ingestion of the food, to study the electrical response activity after ingesting food. The electrical control activity measured in cycles per minute in the jejunum of the animals in the control group presented activity in accordance with the literature with each gastric segment, presenting specific ECA, due to the differences in the electrical response potential, where on average the fundus presented a lower activity because of the characteristics of its quiescent cells, while the body and antrum presented greater activity, being more relevant in the antrum, a naturally more active area. The majority of the studies observe a poorer ECA greater than that of the gastric fundus of the animals within the present study. This fact is probably due to a more distal positioning of the electrodes in this experiment or a graphic interpretation of the contraction, based exclusively and only on the electrical activity.

The electrical activity in the gastric fundus is a matter of discussion. Despite the consideration of a inert segment $t^{(3,30)}$, the identification of the electrical activity on the gastric fundus, in the normal stomach as well as the excluded stomach is owed to the greater sensitivity of the employed method (bipolar electrodes), associated with the application of fast fourier transform (FFT), in which there is a greater sensitivity, thus permitting the identification of small variations in the electrical activity (Figure 1). The number of cycles encountered was in the region of 5 to 6 per minute, similar to those related in the literature ${ }^{(9,26,31)}$.

However, a significant statistical reduction was identified with relation to the number of cycles/minutes of the ECA in the gastric fundus, body and antrum. As the vagal innervation remains intact in this type of surgery, it can be considered that the gastric muscular section, as well as the non-distensibility determined by the food and gases ingested can have an influence over this type of depolarization.

ECA in the control group after ingestion, behaved in a homogenous manner, and did not present any differences between the various gastric segments studied.

Statistical differences were observed in ECA of the RYGBP group, after feeding, when the fundus was compared to the body and the body to the antrum. However, no statistical differences were identified when the two groups were compared.

Thus, it was concluded that in spite of a decrease in the number of cycles/minutes of ECA, in both the fasting and postprandial periods, an electromyographic standard of depolarization was maintained. The ERA of the control group, after ingestion, demonstrated a markedly greater activity than that of the RYGBP group, principally at the fundus and antrum levels, being statistically significant. In the control group animals an electrical response activity with a statistical difference was identified only when the fundus was compared to the antrum. While in the experimental group, a difference was identified when the body was compared to the fundus, and the body to the antrum.

In summary, despite the reduction in electrical control and response activities, it has been proven that the excluded stomach presents and maintains the same electromyographic standards of motility, and continues to respond to dietary stimuli, indicating that the intrinsic electrical activity persist in the longitudinal muscle layer.

The are few reports in the literature related to excluded stomach diseases, such as tumors, ulcers, atonia, bacterial proliferation, etc.. The proof of the existence of a well-defined electrical standard would justify the low incidence of these pathologies. Nonetheless, further studies, seeking to relate bacteriological, hormonal profiles and the production of oncogens, need to be conducted with a certain urgency, due to the high demand for the RYGBP procedure. 
Ferraz AAB, Leão CS, Campos JM, Coelho ARB, Zilberstein B, Ferraz EM. Estudo experimental da atividade elétrica do estômago excluso na gastroplastia vertical com reconstituição em Y-de-Roux. Arq Gastroenterol. 2007;44(2):162-7.

RESUMO - Racional - Dentre a grande diversidade de opções cirúrgicas para obesidade mórbida, a gastroplastia vertical com reconstituição em Y-de-Roux, tornou-se extremamente popular. Dados concernentes à fisiologia do estômago excluído são limitados, desde que este segmento produzido pela cirurgia é inacessível a qualquer endoscopia ou para estudos de radiológicos de contraste. Objetivo - Avaliar a atividade de mioelétrica do estômago excluído e sua resposta à alimentação. Métodos - Um protocolo experimental foi conduzido para avaliar no pós-operatório a motilidade do estômago excluído em cães submetidos ao procedimento de gastroplastia vertical com reconstituição em Y-de-Roux. Dois grupos de cinco animais foram estudados durante o período de jejum e pós-prandial, registrando-se a resposta elétrica e atividades de controle. Ambos, o grupo de controle e o grupo operado, receberam três pares de eletrodos colocado em três pontos do estômago excluso: fundo, corpo e antro. O registro de dados foi executado depois da completa resolução de íleo paralítico e analisado com DATAQ Inst série 200. Resultados - Sob as condições deste estudo sugerem: 1 . o estômago excluso mantém o mesmo padrão de motilidade; 2. a atividade elétrica de controle e a atividade elétrica de resposta foi significativamente reduzida durante o jejum quando comparados ambos os grupos e 3. a atividade elétrica de resposta mantém os mesmos padrões do estômago normal, embora de maneira estatisticamente reduzida. Conclusões - A atividade elétrica do estômago excluso durante o procedimento de gastroplastia vertical com reconstituição em Y-de-Roux manteve o mesmo padrão do estômago íntegro, mas com número estatisticamente reduzido de contrações.

DESCRITORES - Obesidade mórbida. Cirurgia bariátrica. Gastroplastia. Anastomose em Y-de-Roux. Cães.

\section{REFERENCES}

1 Ando M. An electromyographic study on the canine gastric motility following segmenta gastrectomy with selective proximal vagotomyl. Nippon Heikatsukin Gakkai Zasshi. 1983;19:527-40.

2 Balsiger BM, Murr MM, Mai J, Sarr MG. Gastroesophageal reflux after intact vertical banded gastroplasty: correction by conversion to Roux-en-Y gastric bypass. J Gastrointest Surg. 2000;4:276-81

3 Bass P, Code C, Lambert EH. Electric activity of gastroduodenal junction. Am J Physiol. 1961;201:687.

4 Bradley SC, Nguyen NT, Wolfe BM. Late gastrointestinal hemorrage after gastric bypass. Obes Surg. 2002;12:404-407.

5 Brambs HJ, Duda SH, Rieber A. Treatment of bile duct stones: value os laser lithotripsy delivered via percutaneous endoscopy. Eur Radiol. 1996;6:734-40.

6 Capella RF, Capella JF, Mandac H. Vertical banded gastroplasty - Gastric bypass: preliminary report. Obes Surg. 1991;1:389-95.

7 Cariani S, Vittimberga G, Grani S, Lucchi A, Guerra M, Amenta E. Functional Roux-en-Y gastric bypass to avoid gastric exclusion: 1 year results. Obes Surg. 2003;13:788-91.

8 Coelho JCU, Pupo CA, Campos ACL, Moss AA Jr. Electromyographic activity of the gastrointestinal tract following cholecystectomy. World J Surg. 1990;14:523-27.

9 Condon RE, Cowles VE, Ferraz AA, Carilli S, Carlson ME, Ludwig K, Tekin E, Ulualp K, Ezberci F, Shoji Y. Human colonic smooth muscle electrical activity during and after recovery from postoperative ileus. Am J Physiol. 1995;269:G408-17.

10 Cordeiro F, Ferraz EM. H. pylori and gastroplasty in the treatment of morbid obesity. Am J Gastroenterol. 2001;96:605-6.

11 Ferraz AAB, Wanderley GJP, Santos MA Jr, Mathias CA, Araújo JGC Jr, Ferraz EM. Effects of propanolol on human postoperative ileus. Dig Surg. 2001;18:305-10.

12 Fobi MAL, Lee H, Flemming A. The surgical technique of the banded Roux en Y gastric bypass. J Obesity Weight Reg. 1989;8:99-102.

13 Halpern NB, Shepard RB, Laws HL, Jimenez H, Aldrete JS. Effects of partitioning operations on the electrical activity of the stomach. J Surg Res. 1982;32:275-82.

14 Hamilton JW, Bellahsene BE, Reichelderfer M, Webster JG, Bass P. Human electrogastrograms. Comparison of surface and mucosal recordings. Dig Dis Sci. 1986;31:33-9.

15 Jaffin BW, Knoepflmacher P, Greenstein R High prevalence of asymptomatic esophageal motility disorders among morbidly obese patients. Obes Surg. 1999;9:390-5.

16 Konegawa R. Electromyographical study on the residual stomach following proximal gastrectomy. Nippon Heikatsukin Gakkai Zasshi. 1978;14:29-41.
17 Kuwashima T. Effects of various types of vagotomy on electrical and contractile activities of the canine stomach. Nippon Heikatsukin Gakkai Zasshi. 1977;13:55-67.

18 Leão CS, Campos JM, Câmara-Neto RD, Bacelar TS. Avaliação da atividade mioelétrica do trato gastrointestinal em cães: Avaliação de um sistema de fixação de eletrodos. Acta Cir Bras. 2002;17:394-402.

19 Lord RV, Edwards PD, Coleman MJ. Gastric cancer in the bypassed segment after operation for morbid obesity. Aust NZ J Surg. 1997;7:580-2.

20 MacGregor AM, Pikens NE, Thoburn EK. Perforated peptic ulcer following gastric bypass for obesity. Am Surg. 1999;65:222-5.

21 McIntryre JA, Deitel M, Baida M, Jalil S. The human electrogastrogram at operation a preliminary report. Can J Surg. 1969;12:275-84.

22 Morishita K. Electromyographic study on the propagation mechanism of canine gastric electrical activity. Nippon Heikatsukin Gakkai Zasshi. 1979;15:281-94.

23 Pope GD, Finlayson SRG, Birkmayer JD. Life expectancy benefits of gastric bypass surgery. Presented at 88 American College of Surgeons, San Francisco, 2002.

24 Printen KJ, Owensby M. Vagal innervation of the bypassed stomach following gastric bypass. Surgery. 1978;84:455-6.

25 Printen KJ, LeFavre J, Alden J. Bleeding from the bypassed stomach following gastric bypass. Surg Gynecol Obstet. 1983;156:65-6.

26 Sarna SK. Gastrointestinal electrical activity: terminology. Gastroenterology. 1975;68:1631-5.

27 Seymour K, Mackie A, McCauley E, Stephen JG. Changes in esophageal function after vertical banded gastroplasty as demonstrated by esophageal scintigraphy. Obes Surg. 1998;8:429-33.

28 Shimasaki Y. Electromyographic study of the canine stomach after transection and mucosal bridge anastomosis. Nippon Heikatsukin Gakkai Zasshi. 1979;15:267-79.

29 Sundbom M, Nyman R, Hedenstrom H, Gustavsson S. Investigation of the excluded stomach after Roux-en-Y gastric bypass. Obes Surg. 2001;11:25-7.

30 Van Dielen FMH, Cock AFC, Daams F, Brummer RJM, Greve JWM. Gastric myoelectrical activity in morbidly obese patients before and 3 months after gastric restrictive surgery. Obes Surg. 2003;13:721-7.

31 Verhagen MAMT, Van Schelven LJ, Samsom M, Smout AJPM. Pitfalls in the analysis of electrogastrophraphic recordings. Gastroenterology. 1999;117:453-60.

32 Wadden TA, Sarwer DB, Womble LG, Foster GD, McGuckin BG, Schimmel A. Psychosocial aspects of obesity and obesity surgery. Surg Clin North Am. 2001;81:1001-24. 